\title{
Subject Review: A Comparison of Lightweight Concrete Made With Sawdust
}

\section{Dr. Salam Salman Chiad Alharishawi ${ }^{1}$, Nagham Rajaa ${ }^{2}$ and Hadi Salih Mijwel Aljumaily ${ }^{3}$}

${ }^{1}$ Ph. D., Eng., Mustansiriyah University, College of Engineering, Environmental Engineering Department, Baghdad, Iraq

${ }^{2}$ Assist Lecturer., Eng., Mustansiriyah University, College of Engineering, Highway and Transportation Engineering Department, Baghdad, Iraq

${ }^{3}$ Assist. Prof., Eng., Mustansiriyah University, College of Engineering, Environmental Engineering Department, Baghdad, Iraq

\begin{abstract}
:
Lightweight concrete is a very useful and advantageous material in the modern civil industry. It is lighter than normal-weight concrete. This paper investigates the review of the significant applications and advantages of using lightweight concrete in the area of civil engineering. Also, therefore, the use of lightweight concrete has a great impact on developing countries as it permits design flexibility and substantial saving in the cost of construction. In this paper, the background for many experimental studies of lightweight concrete made with sawdust is provided and a comparison between these studies.
\end{abstract}

Keywords: Lightweight concrete; Normal weight concrete; Sawdust; Wood waste.

\section{INTRODUCTION}

Sawdust is produced in thousands of tons in the whole world annually from wood products. Wood wastes cause a different environmental problem. To solve these problems, researchers have investigated using it in lightweight concrete production in the area of civil engineering.

The Lightweight concrete is usually used in construction materials with cement as the major element. Recently, more than 4.6 billion tons of Portland cement are manufacture per year in the whole world. The number is expected to increase to 5.6 billion by 2050 and with the rapidly urbanizing of various poor countries. A large amount of Portland cement is responsible for the emissions of around $9 \%$ of $\mathrm{CO}_{2}$ gas into the atmosphere [1]. However, huge amounts of solid waste of wood pose a danger to the environment because of the small biodegradability of various solid waste. It is very necessary to develop a rational approach to wood waste disposal which addresses both the economy and environmental protection [2-10]. The field of study on the assessment of the application of solid waste (like a wood waste) in concrete mixtures has gained popularity in the last years. The use of wood waste (sawdust) as fine aggerate to production lightweight concrete [11-17].

recently, many methods suggested the use of lightweight concrete made with solid waste. In this paper, work conducted a deep analysis of lightweight concrete made with sawdust that is based on adding it to the mixtures. The residual of this research article arranged as follows: In Section 2 the literature survey of some Pervious Studies that proposed in the latest decade.

\section{LITERATURE SURVEY}

Joy et al. [18] investigated the average compressive strength, flexural and splitting tensile at different concrete mixture proportions. They cast several various cubes, cylinders and beams by substituent sand with wood waste (sawdust) by weight 15 , 20, 25 and $30 \%$. Based on the study on sawdust, the average compressive strength found for the substituent of sand with $25 \%$ recycled wood was shown to be the optimum mix of concrete. 
Abdullah et al. [19] checked the compressive strength of concrete and analyze its effect on the construction cost. They cast (150 $\mathrm{x} 150 \mathrm{x} 150) \mathrm{mm}$ cube \& evaluated the average compressive strength of lightweight concrete at 7, 14, 21 and 28 days by replacing sand from $0 \%$ to $50 \%$ (in percentage gap of 10). Based on the investigation following conclusions were made i.e. Sawdust has no significant positive effect on the average compressive strength of lightweight concrete. Differences in the average compressive strength results are observable to the fact that it is hard to obtain recycle wood which is not a mixture of numerous species.

Osei et al. [20] have carried an experiment on the topic of the effect of substituent fine aggregate with sawdust on the properties of lightweight concrete production. A concrete mix of 1:2:4 was used as control while recycling wood (sawdust) was used to substituent by volume with 25, 50, 75 and $100 \%$ of sand. In this study, the effects of the substituent of fine aggregate with sawdust on the average strength and density were investigated. the results have shown the average compressive strength and density of lightweight concrete decreased as the percentage replacement of sand by sawdust rise.

Dadzie et al. [3]. and Boob [21] established that sand Crete blocks made by partially substituting fine aggregate with sawdust provided the best and desired results from a 1:6 (cement: sand + sawdust) (85\% sand $+15 \%$ sawdust) mix ratio. The average compressive strength got from blocks for this mix proportion was $4.5 \mathrm{~N} / \mathrm{mm}^{2}$. This is a very good result for lightweight concrete (blocks) made with recycled wood (sawdust) substituent of not more than $10 \%$ when calculated to the minimum requirement.

Kupolati et al. [22] studied the utilization of recycling wood (sawdust) as a partial substituent of fine aggregate for the lightweight concrete production of improving the environment. Recycle wood (sawdust) was used as a partial substituent by volume for sand. The average examined compressive strength values of the lightweight concrete produced were less than the minimum values of 4.0 MPa.

\section{COMPARATIVE ANALYSIS OF THE LIGHTWEIGHT CONCRETE}

Table 1 will determine the comparison between preceding lightweight concrete made from sawdust.

Table 1. Summary of Comparative for Pervious Studies on Sawdust Replacement of Sand in Concrete Production

\begin{tabular}{|c|c|c|c|}
\hline Reference & year & $\begin{array}{c}\text { Replacement of Material Proc } \\
\text { edure }\end{array}$ & Research Findings \\
\hline $\begin{array}{l}\text { Alharishawi } \\
\text { et. al. [11] }\end{array}$ & 2020 & $\begin{array}{l}\text { Sand replaced by weight with } \\
0,5,10,15,20 \text { and } 25 \%\end{array}$ & $\begin{array}{l}\text { Average results for comp. strength was detected as } 30.13 \text {, } \\
21.39,13.46,11.23,8.02 \text { and } 6.49 \mathrm{~N} / \mathrm{mm}^{2} \text { respectively. } \\
\text { Average results for tensile strength was detected as } 3.92 \text {, } \\
3.02,2.75,2.28,1.79 \text { and } 1.64 \mathrm{~N} / \mathrm{mm}^{2} \text { respectively. }\end{array}$ \\
\hline $\begin{array}{l}\text { Dadzie et al. } \\
\text { [3]. Ghana }\end{array}$ & 2018 & $\begin{array}{l}\text { Sand replaced by volume with } \\
10 \%, 20 \%, 30 \% \text { and } 40 \% \\
\text { sawdust }\end{array}$ & $\begin{array}{l}\text { Average results for comp. strength was detected as } 3.05 \\
\mathrm{MPa} \text { at } 10 \% \text { replacement. }\end{array}$ \\
\hline $\begin{array}{l}\text { Garcez et. al } \\
\text {. [23] }\end{array}$ & 2016 & $\begin{array}{l}\text { Sand replaced by volume with } \\
0,25,50,75 \text { and } 100 \%\end{array}$ & $\begin{array}{l}\text { Average results for } \\
\text { comp. strength was as } 17.85,14.01,9.17,7.53 \text { and } 4.12 \\
\mathrm{~N} / \mathrm{mm}^{2} \text { respectively. } \\
\text { Average results for tensile strength was } \\
\text { detected as } 2.29,1.75,1.26,1.23 \text { and } 0.78 \mathrm{~N} / \mathrm{mm}^{2} \\
\text { respectively. }\end{array}$ \\
\hline $\begin{array}{l}\text { Chandana, } \\
\text { and } \\
\text { Mynuddin } \\
{[24]}\end{array}$ & 2015 & $\begin{array}{l}\text { Sand replaced by weight with } \\
0,5,10,15 \text { and } 20 \%\end{array}$ & 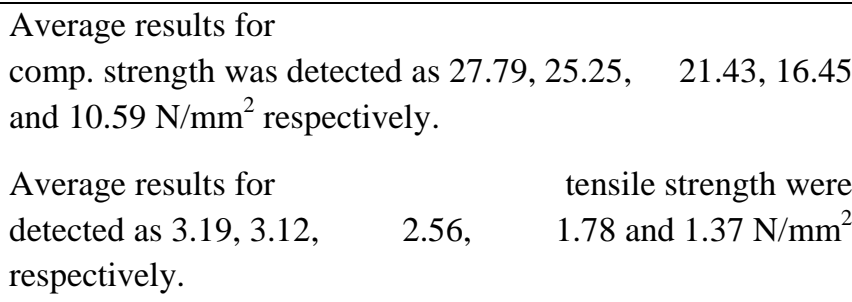 \\
\hline
\end{tabular}


International Journal of Engineering Research And Advanced Technology, Vol.7 (2), February -2021

\begin{tabular}{|c|c|c|c|}
\hline $\begin{array}{c}\text { Kumar et. al } \\
.[25]\end{array}$ & 2014 & $\begin{array}{l}\text { Sand replaced by weight with } \\
0,10,15 \text { and } 20 \%\end{array}$ & $\begin{array}{c}\text { Average results for } \\
\text { comp. strength was detected as } 20.58,18.16,18.32 \text { and } 20.5 \\
1 \mathrm{~N} / \mathrm{mm}^{2} \text { respectively. }\end{array}$ \\
\hline Boob. [21] & 2014 & $\begin{array}{l}\text { Sand replaced by weight with } \\
0 \%, 5 \%, 10 \%, 15 \% \& 20 \% \text {. }\end{array}$ & Average results for comp. strength was detected $4.5 \mathrm{MPa}$ \\
\hline Saeed [26] & 2013 & $\begin{array}{l}\text { Sand replaced by weight with } \\
0,5,10,15,20,25,30 \\
\text { and } 35 \%\end{array}$ & $\begin{array}{l}\text { Increasing of comp. strength and Flexural strength } 50 \% \text {. } \\
\text { Reduction of thermal conductivity. }\end{array}$ \\
\hline $\begin{array}{l}\text { Cheng et. al. } \\
\text { [27] }\end{array}$ & 2013 & $\begin{array}{l}\text { Sand replaced by weight with } \\
\qquad 0,3,5,7 \text { and } 10 \%\end{array}$ & $\begin{array}{l}\text { The optimum replacement was } 5 \% \text {. Reduction of thermal } \\
\text { conductivity. }\end{array}$ \\
\hline $\begin{array}{c}\text { Adebakin } \\
\text { And } \\
\text { Adeyemi } \\
\text { [28] }\end{array}$ & 2012 & $\begin{array}{l}\text { Sand replaced by volume with } \\
\quad 0,10,20,30 \text { and } 40 \%\end{array}$ & $\begin{array}{l}\text { Average results for comp. strength was detected } 4.27 \text { to } 1.81 \\
\qquad \mathrm{~N} / \mathrm{mm}^{2} \text { for } 0 \text { to } 40 \% \text { sand replacement. }\end{array}$ \\
\hline $\begin{array}{l}\text { Kupolati et } \\
\text { al. [22] }\end{array}$ & 2012 & $\begin{array}{l}\text { Sand replaced by weight with } \\
\qquad 1,2,11,13 \text {, and } 73 \%\end{array}$ & $\begin{array}{c}\text { Average results for } \\
\text { comp. strength was detected as } 4.00 \text { to } 6.00 \mathrm{~N} / \mathrm{mm}^{2} \\
\text { for } 0 \text { to } 40 \% \text { sand replacement. }\end{array}$ \\
\hline $\begin{array}{l}\text { Akinwonmi } \\
\text { [29] }\end{array}$ & 2012 & $\begin{array}{l}\text { Sand replaced by weight with } \\
0,20,40,65,80 \text { and } 100 \%\end{array}$ & $\begin{array}{c}\text { The optimum replacement was } 20 \% \text {. Average results for } \\
\text { tensile strength was detected } 15.91 \mathrm{~N} / \mathrm{mm}^{2} \text {. }\end{array}$ \\
\hline
\end{tabular}

\section{CONCLUSIONS}

In this research article, we a timeline reviewed various approaches for lightweight concrete made with sawdust within the period (2012-2020). Using sawdust becomes very significant in the production of lightweight concrete. These mothed are studied and analyzed wholly to increase the efficiency of the properties of concrete. The synopsis of this study, all these methods are useful for concrete production. Wood sawdust is considered a waste material and can use to make lightweight concrete and which possesses heat transfer of long duration. Moreover, it is the perfect way to reduce sold wood waste and produce lightweight concrete to be used in industrial construction. Every experimental study has several drawbacks and benefits and therefore novel technologies have been sophisticated.

\section{Acknowledgements}

The author would like to thank Mustansiriyah University, in Baghdad, Iraq, for their help in this work.

\section{REFERENCES}

1. Lehne, J. \& Preston, F. (2018). Making Concrete_Change: Innovation in Low-carbon Cement and Concrete. Chatham House Technical Report, the Royal institute of International Affairs London: Energy, Environment and Resources Department, pp. $3-6$.

2. Duque-Acevedo, M.; Belmonte-Ureña, L.J.; Cortés-Garcia, F.J.; Camacho-Ferre, F.Agriculturalwaste: Review of the evolution, approaches and perspectives on alternative uses. Glob. Ecol. Conserv. 2020, 22, e00902.

3. Dadzie, D. K., Dokyi, G. Q., and Niakoh, N. (2018). Comparative Study of the Properties of Sandcrete Blocks Produced with Sawdust as Partial Replacement of Sand. International Journal of Scientific \& Engineering Research, 9(3), 2229-5518. 
4. Adebakin, I., and Adeyemi, A., (2012). Uses of Sawdust as Admixture in Production of Lowcost and Lightweight Hollow Sandcrete Blocks. American Journal of Scientific and Industrial Research, 3(.6), 458-463.

5. Mageswari M. and Vidivelli B. (2010). The Use of Sawdust Ash as Fine Aggregate Replacement in Concrete. Journal of Environment Research and Development, 3 (3), 720 - 726.

6. Paramasivam, P., and Loke, Y. O. (1980). Study-of-sawdust-concrete. International-Journal-of-Cement-Composites-andLightweight-Concrete. The International Journal of Lightweight Concrete., 2(1), 57-61.

7. Sales, A. S., Santos, F.R., Zimer, and W. M. (2010). Lightweight composite concrete produced with water treatment sludge and sawdust: Thermal properties and potential application. Construction and Building Materials, 24(12), $2446-2453$.

8. Omaran, S.M., Alghamdi, A.A., Alharishawi, S.C. and Hains, D.B. (2019). Integrating BIM and Game Engine for Simulation Interactive Life Cycle Analysis Visualization. In Computing in Civil Engineering. Visualization, Information Modeling, and Simulation. Reston, VA: American Society of Civil Engineers. (120-128).

9. Al-hafiz, A.M., Chiad, S.S. and Farhan, M.S. (2013). Flexural strength of reinforced concrete one-way opened slabs with and without strengthening. Australian Journal of Basic and Applied Sciences, 7(6),.642-651.

10. Chiad, S.S., (2013). Shear Stresses of Hollow Concrete Beams. Journal of Applied Sciences Research, 9(4), .2880-2889

11. Alharishawi, S.S.C, Abd, H., Abass, S. (2020). Employment of Recycled Wood Waste in Lightweight Concrete Production. Archives of Civil Engineering, Vol. 4-20

12. Jian, H. (2014). The Implementation of Waste Sawdust in Concrete. Advanced Materials Research, 941-944, 849-853. doi: 10.4028/www.scientific.net/AMR.941-944.849

13. Aberdeen. (1971). Waste Materials in Concrete - Can concrete be made from broken glass? sawdust? plastics? mine wastes? garbage frit? Concrete Construction.

14. Bdeir, L. M. H. (2012). Study Some Mechanical Properties of Mortar with Sawdust as a Partially Replacement of Sand. Anbar Journal for Engineering Sciences, 5(1), 22-30.

15. Taoukil, D., bouardi, A. E., Ezbakhe, H., and Ajzoul, T. (2011). Thermal Proprieties of Concrete Lightened by Wood Aggregates. Research Journal of Applied Sciences, Engineering and Technology.

16. Felix, F., Udoeyo., and Dashibil, P. U. (2002). Sawdust Ash as Concrete Material. Journal of materials in civil engineering, 14, 173-176. doi: 10.1061//asce/0899-1561/14:2/173.

17. Ganiron, T., Jr. (2014). Effect of Sawdust as Fine Aggregate in Concrete Mixture for Building Construction. International Journal of Advanced Science and Technology, 63, 73-82. doi: 10.14257/ijast.63.07

18. Albert M Joy and Amal Jyothi "Partial Replacement of Fine Aggregate with Sawdust for Concrete" International Journal for Technological Research in Engineering Volume 3, Issue 9, May-2016

19. A. Abdullahi, "Partial Replacement Of Sand With Sawdust In Concrete Production" published in 3rd Biennial Engineering Conference, Federal University of Technology, Minna, May, 2013

20. Daniel Yaw Osei and Emmanuel Nana Jackson "Compressive Strength Of Concrete Using Sawdust As Aggregate" International Journal of Scientific \& Engineering Research, Volume 7, Issue 4, April-2016.

21. Boob, T.N. (2014) Performance of Sawdust in Low-Cost Sandcrete Blocks. Amer ican Journal of Engineering Research , 3 , 197-206.

22. Kupolati, W.K., Grassi, S. and Frattari, A. (2012) Environmental Greening through Utilization of Sawdust for Production of Bricks. OIDA International Journal of Sustainable Development, 4, 63-78.

23. Garcez, M.R., Santos, T, Garcez, E.O., Rohden, A.B., “Assessment of Physical and Mechanical Properties of Sawdust Concrete using Ultrasonic Pulse Velocity”, Database of Nondestructive Testing (NDT) [ISSN: 14354934], Volume 1, 2016.

24. Chandana, P.S., and Mynuddin, S.A., "ExperimentallStudy on Strength of Concrete by Partial Replacement of Fine Aggregate with Sawdust and Robosand”, International Journal and Magazine of Engineering, Technology, Management and Research, Volume 2, No. 9, pp. 338-246, 2015.

25. Kumar, D., Singh, S., Kumar, N., and Gupta, A., "Low Cost Construction Material for Concrete as Sawdust", Global Journal of Researches in Engineering, Volume 14, No. 4, pp. 3428-3430, 2014. 
26. Saeed, H.H., "Pretreatment of Sawdust for Producing Sawdust Concrete", Journal of Engineering \&Applied Sciences, Volume 31, No.3, pp. 541-549. 2013.

27. Cheng, Y., You, W., Zhang, C., Li, H., and Hu, J., "The Implementation of Waste Sawdust in Concrete”, Engineering, Scientific Research, Volume 5, pp. 943-947. 2013.

28. Adebakin, I., and Adeyemi, A., "Uses of Sawdust as Admixture in Production of Lowcost and Light-weight Hollow Sandcrete Blocks”,American Journal of Scientific and Industrial Research, Volume 3, No.6, pp. 458-463. 2012.

29. Akinwonmi, A.S.,"Fracture Behavior of Concrete with Sawdust Replacement under Uniaxial Compressive", International Journal of Innovative Research \& Development, Volume 1, No.9, pp.155-163.2012.

\section{Author corresponding emails.}

Dr. Salam Salman Chiad Alharishawi ${ }^{1}$, Nagham Rajaa ${ }^{2}$ and Hadi Salih Mijwel Aljumaily ${ }^{3}$

1 e-mail: dr.salam.chiad@uomustansiriyah.edu.iq

2 e-mail: Nagham_z77@uomustansiriyah.edu.iq

3 e-mail: hadi.aljumaily@uomustansiriyah.edu.iq 